自然界の物理因子を利用した地下水調査法

竹内篤雄 $*$. 渡辺知恵子 $* *$

\title{
Investigation Method of Groundwater using Physical Factor of the Natural World
}

\author{
Atsuo TAKEUCHI * and Chieko WATANABE ** \\ キーワード： $1 \mathrm{~m}$ 深地温探査、多点温度榆層、流向流速測定、自然電位法、地下水流動調查
}

\section{1.はじめに}

地域開発が進むに従い、我々と地下水との関わ りはますます複雑になってきている。平地では大 雨・集中豪雨による切り土・盛り土などの斜面崩 壊、河川増水による堤防破壞、ため池の堤体漏水 に悩まされ、山地では長雨・大雨・融雪期に数多 く発生する地すべり・山崩れ等の斜面災害に悩ま されている。これらの諸災害の原因は、浅層地下 水あるいは降水浸透に依存している場合が多い。

また、時代と共に地域開発も進み、大規模な地 下構造物建設による浅層地下水の枯渴、化学工場 などの排水問題、産業廃車物に伴う地下水污染に よる生活用水の使用制限の問題などが生じてい る。このように、地下水は我々の生活に対し多岐 にわたって多種多様な影響を及ぼしており、高密 度化された社会生活の中に执いては、マクロな考
えだけでは十分に対処しきれない問題が生じてき ている。

これまでに多くの研究者・技術者が行ってきた 成果を顧みると、地下水は単に地下水層として一 様且つ層状に存在する以外に、いわゆる「水ミ チ」として水脈状に存在している場合も多いこと が指摘されている（竹内: 1975）。また、土層区分 から一枚の带水層と見なされる場合に扔いても、 異なる水位・水頭を有する何枚かの帯水層で構成 されており、それぞれの带水層が地盤災害・地下 水障害に及ぼす影響の度合いが異なっていること も指摘されている。

したがって、先述した諸問題を少しでも現実に 近い形で解決しょうとするならば、「水ミチ」状 に存在する地下水と垂直方向並びに水平方向に何 枍か存在する性質の異なる帯水層（これを「層別 地下水」あるいは「領域別地下水」と呼ぶ）につ

自然地下水調査研究所

Natural Groundwater Research Institute,

** 株式会社 神陽技研 (

Shin' you Geo-engineering. Co., Ltd, 
いて、それぞれの現状に合致した詳しい情報を得 る必要がある。つまり自然状態に打ける地下水の 「あるがままの姿」を知り、それに対して適切な 処置を講じることが大切であると考える。

これらの問題を解決する一手法として、我々は 技術的な解析に際し主観が入りにくく、且つ環境 に不要な負荷の掛からない「温度」あるいは自然 界に存在している「電気」という物理的因子を用 いた地下水調查法に注目した。この調査法はこれ までにも様々な試行錯誤がなされ、研究上はかな りの成果が上げられていることは先人の示すとこ ろである。しかし、現場の調査手法としてはまだ 高い評価を得ていなかったように思われる。ここ では「温度」と「電気」を利用した地下水調査法 について紹介する。

\section{2. 温度測定による地下水調查法}

\section{2. $11 \mathrm{~m}$ 深地温探査法}

\section{(1) 概要}

地下浅所（地表面下 $1 \mathrm{~m}$ ）の温度分布状沉を詳 細に測定することにより、地下水脈（「水ミチ」） の存在場所を推定する手法である。

地中に日変化の影響を受け難い深度 $1 \mathrm{~m}$ の孔 を掘り、その孔底の温度を測定する。 $1 \mathrm{~m}$ 深地 温探查は、平常 $1 \mathrm{~m}$ 深地温（「水ミチ」の影響を 受けない場所の $1 \mathrm{~m}$ 深地温）と流動地下水の温度 との差を利用するため、日本では調査最適時期と 不適時期がある。調查対象地域にもよるが一般的 には晚春～初夏（ $5 \sim 6$ 月）と晚秋～初冬（11〜 12月）は不適時期とされている。条件にもよる が、「水ミチ」は地下 $15 \mathrm{~m}$ 程度まで探査可能であ る。以下に本調查法の原理、調查計西立案法、測 定方法等について簡単に述べる。

\section{(2) 原理}

地温測定の原理は、地下浅層を流れる「水三 チ」によって周辺の地温が乱される現象を利用し たものである(図一 1)。

夏秋季には周辺地温が流動地下水の温度よりも 高いために、「水ミチ」直上とその周囲は地温が 低くなる方向に乱される。一方、春冬季には逆に 周辺地温が流動地下水の温度よりも低くなるため に、「水ミ于」直上とその周辺は温度が高くなる

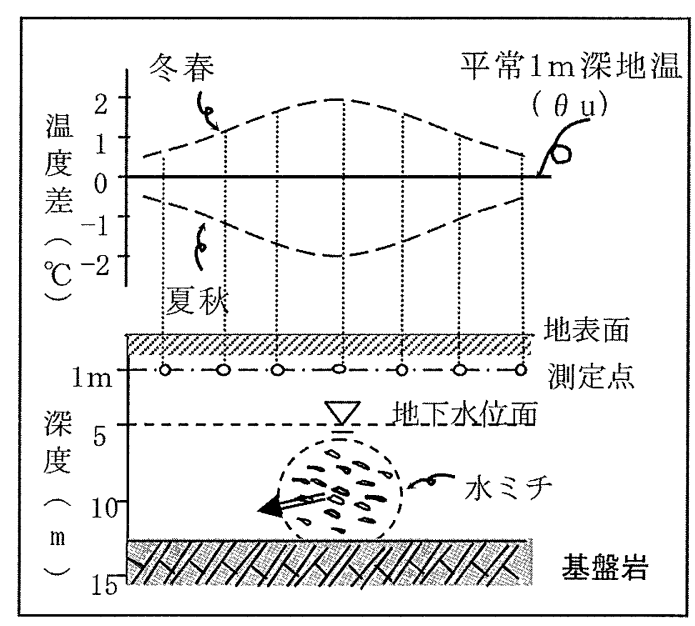

図一 1 地下水流脈による平常 $1 \mathrm{~m}$ 深地温への影響

方向に乱される。

\section{(3) $1 \mathrm{~m}$ 深地温探查の実施時期}

地温測定調査法は、流動地下水温と平常 $1 \mathrm{~m}$ 媣地温との差を利用した調查法であるため、両者 が等しい温度を示寸時期にはこの調査法の適用は 難しい。過去の長期観測 (「水ミチ」の湧水地点の 水温と $1 \mathrm{~m}$ 深地温) 結果によると、 $1 \mathrm{~m}$ 深地温は $\pm 7 \sim 10^{\circ} \mathrm{C}$ とかなり大きな年変化を示すが、流 動地下水の年変化は土1 $\sim 2{ }^{\circ} \mathrm{C}$ 程度でかなり小 さい(図-2)。

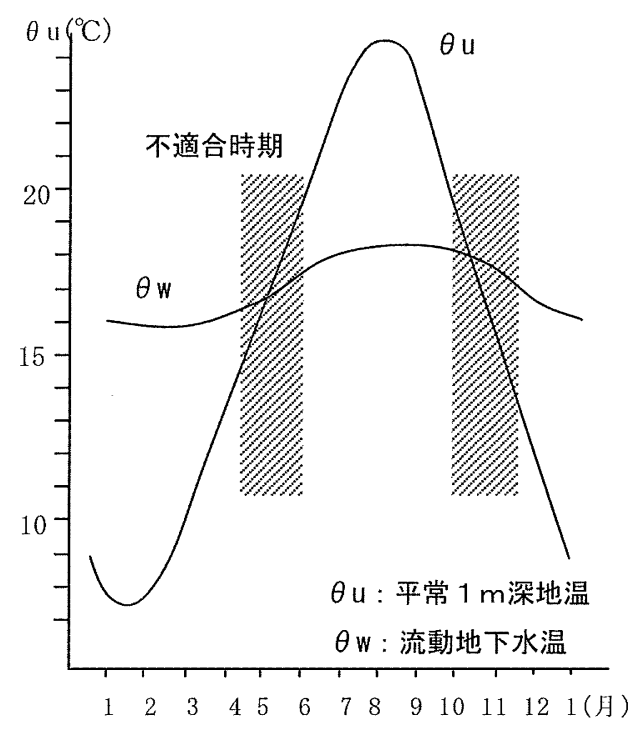

图一 $21 \mathrm{~m}$ 深地温の年変化と地温調査実施適切時期 
$1 \mathrm{~m}$ 深地温探査結果から「水ミチ」の規模と存 在深度を算出するためには、平常 $1 \mathrm{~m}$ 墚地温と 流動地下水の温度との差は $|2.5|{ }^{\circ} \mathrm{C}$ 以上あるこ とが望ましいとされている（竹内:1983）。この点 を考慮して日本に扔ける $1 \mathrm{~m}$ 深地温探査による 地下水流脈調査の可能時期を求めると、2月を中 心とした厳寒期と 8 月を中心とした厳暑期である ことが示された。

これらの時期に $1 \mathrm{~m}$ 深地温探査を実施すると良 好な結果を得ることができる。ただ、| $2.5 \mid{ }^{\circ} \mathrm{C}$ 以 下の温度差で実施した場合でも、地表面の状況 （地形、地質、植生など）が非常に均一である場 合には、よい結果が得られた例もある（竹内他： 1979)。

\section{(4) 測点網の配置方法}

「水ミチ」の流動経路をできるだけ正確に推定 するためには、調査対象地区に適切な測点網を展 開しなくてはならない。これの如何によって調査 結果が大きく左右されるため、調査目的を考慮し た現地踏查を十分に行った上でこれを決める必要 がある。通常は1/1000あるいは1/500の縮尺の地 形図を用いて測点網を描く。測点閒隔は調査対象 物によって左右されるが、最大でも推定される 「水ミチ」の流動経路を横断する形で $20 \mathrm{~m}$ 、流動 経路と平行な方向に $10 \mathrm{~m}$ とする。大規模な河川伏 流水を調査する場合はともかく、これ以上の測点 間隔の広い測点網を設定しても良好な結果を得る ことは難しい。規模の小さい地すべり地の場合は $5 \mathrm{~m} \times 5 \mathrm{~m}$ のように細かい測点網を設定し、長 さ $50 \mathrm{~m}$ 程度のため池の漏水箇所を調査するような 場合には $2 \mathrm{~m} \times 3 \mathrm{~m}$ 程度の測点網を設定する場 合もある。また地下 2 ○ $\mathrm{m}$ に掘削された集水 井の排水孔の存在場所を推定するため $1 \mathrm{~m}$ 間隔 に測点を設けて調査を行い、径 $10 \mathrm{~cm}$ の排水孔の 存在場所を明らかにした例もある（竹内：1983）。

次に標準的な測点網の設定に関して、各調査対 象分野別に示导。

\section{(5) 測定作業手順}

測定作業の手順をフローチャートで示すと下記 のとおりである（図一 3 )。

$1 \mathrm{~m}$ 深地温の測定方法は、決められた測点上 に径 $25 \mathrm{~mm}$ の半鋼製の鉄棒で $1 \mathrm{~m}$ 深の孔を穿ち、 その後 $1 \mathrm{~m}$ 深地温探査用の測温体を挿入する。

\section{表ー 1 測点網の設定例}

\begin{tabular}{|c|c|c|}
\hline 調查対象物 & 測 線 数 - 間 隔 & 測点間隔 (m) \\
\hline 地すべり & $5 \sim 20 \mathrm{~m}$ & $5 \sim 10 \mathrm{~m}$ \\
\hline 堤 防 漏 水 & $2 \sim 3$ 测 線 & $2 \sim 5 \mathrm{~m}$ \\
\hline ため池堤体 & $3 \sim 5$ & $1 \sim 3 \mathrm{~m}$ \\
\hline 小さな「水ミチ」 & $2 \sim 3$ & $1 \sim 2 \mathrm{~m}$ \\
\hline 小さな伏流水 & \multirow{2}{*}{$\begin{array}{c}\text { 流動方向に } \\
\text { 数本 }\end{array}$} & $1 \sim 2 \mathrm{~m}$ \\
\hline 大規模な伏流水 & & $50 \mathrm{~m}$ \\
\hline トンネル切羽 & $\begin{array}{c}100 \mathrm{~m} \\
1 \mathrm{~m}\end{array}$ & $\begin{array}{l}1 \mathrm{~m} \text { : 赤外線放射温度計 } \\
1 \mathrm{~m} \text { : 接触型温度計 }\end{array}$ \\
\hline
\end{tabular}

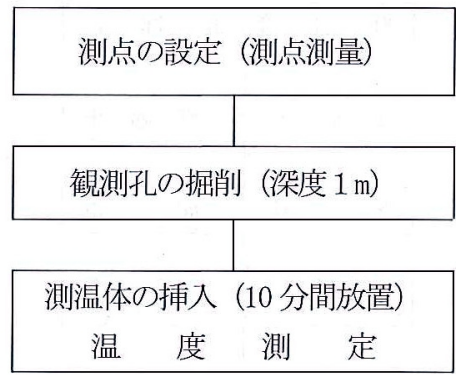

図ー3 作業手順フローチャート

挿入後、約10分経過してからその值を読み取る。 測定された值は測温体番号、埋設時間、読み取り 時間、地況などと共に野帳に記入する。

\section{(6) 使用機器}

使用機器は、 $1 \mathrm{~m}$ 深孔開け用鉄棒類とサーミ ス夕型精密温度計である (写真 -1$)$ 。測温体の

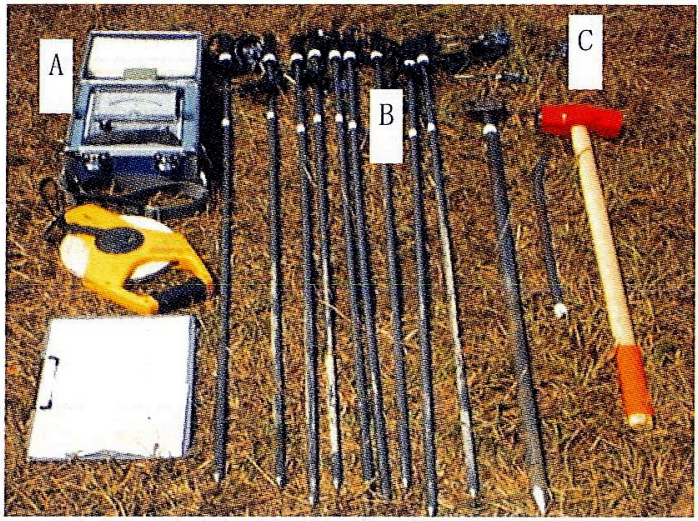

写真一 $11 \mathrm{~m}$ 深地温測定器一式 $A$ ：測定器 $B$ ：測温体 $\mathrm{C}$ ：開孔用半鋼製鉄棒 
精度は土0.1 ${ }^{\circ} \mathrm{C}$ で、検出部はフルスケール $10^{\circ} \mathrm{C}$ と し最小目盛 $0.1^{\circ} \mathrm{C} 、 4$ 段階切り替えで $0 \sim 35^{\circ} \mathrm{C}$ ま で測定できる。

\section{（7）解析方法}

測定值（温度）には、種々の因子による影響が

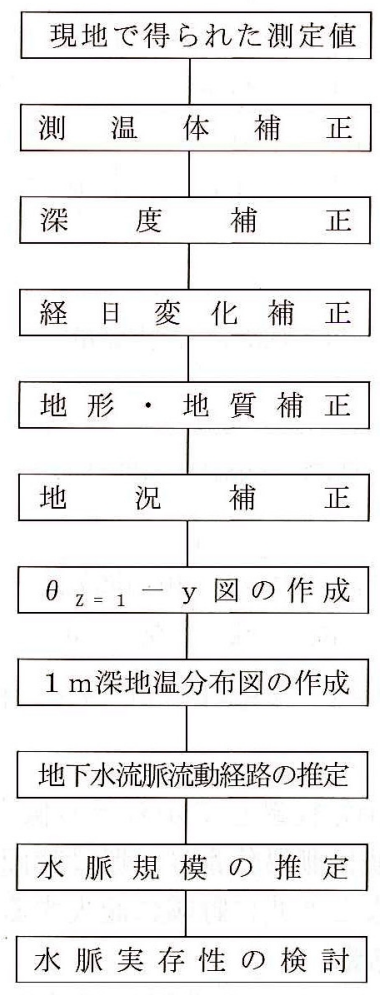

図-4 測定值解析手順
含まれている。したがって、これら諸因子の影響 の度合いを検討し補正する必要がある（図－4）。 各項目の因子の影響を補正した值を $\theta \mathrm{z}=1-\mathrm{y}$ 図（各測点における $1 \mathrm{~m}$ 深地温図）として測線毎 に描く(図一 5 )。これらの図は、地下水流脈の 流動経路および水脈の規模を推定する時に用いら れる。測線毎の結果を並べてみると、温度の高い 部分と低い部分とが系統的に存在していることが 示される。

また、これらの值を平面図にプロットし温度分 布図として表現する（図－6）。この分布図に対 する解釈は、夏秋季であれば低温部に、冬春季で あれが高温部に着目し、地形地質構造やボーリン グ調查等のデータなどを考慮に入れ、地下水流動 経路の推定を行う。

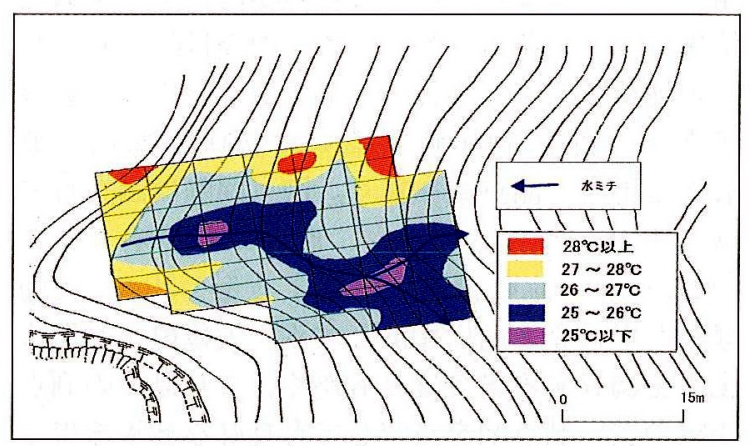

图一 $6 \quad 1 \mathrm{~m}$ 深地温分布図の例

$\left({ }^{\circ} \mathrm{C}\right)$

測線 1

28
27
26
25
24
23
22
21
20

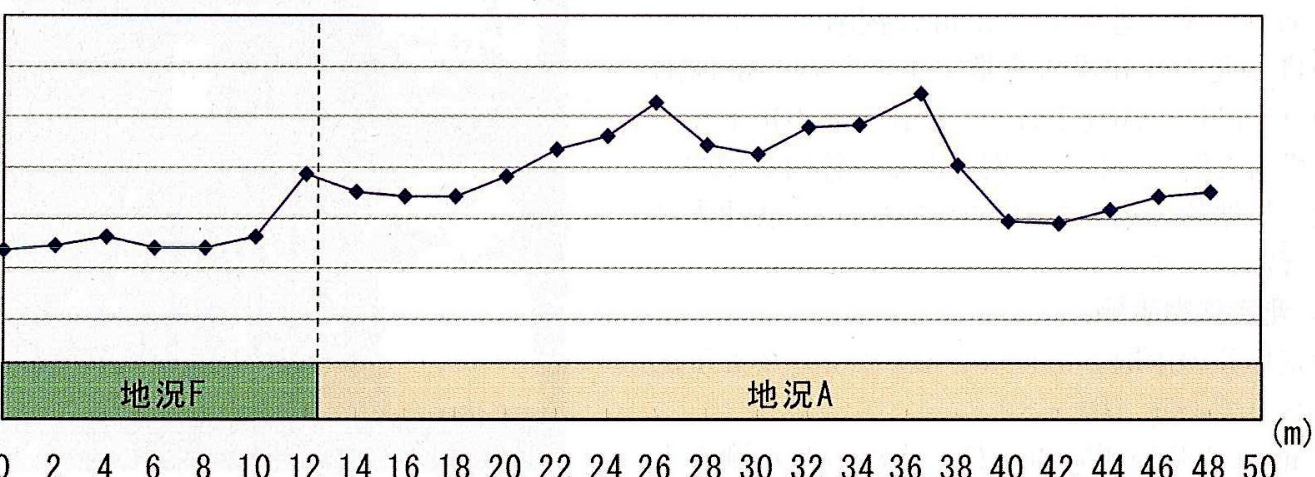

図-5. $\theta z=1-y$ 図の例 


\section{2 多点温度検層}

\section{(1) 概要}

試錐孔内の温度を变化させ、孔内水位以浅並び に以深の地下水流動状況に関する情報を得る検層 法である。これを行うことにより、地下水流動層 の存在媣度、層厚および流動層の性状（不圧層あ るいは被圧層など）、概略の流速についての情報 を得ることができる。

\section{(2) 原理}

自然状態の孔内温度を測定した後、温水注入に より孔内温度を自然状態より大きく変化させ、30 分程度の温度の回復過程を測定する。地下水が流 動している筒所はそれ以外の箇所よりも速く自然 状態の温度に戻るため、地下水流動箇所と数およ びその厚さについての情報を得ることができる。 また、経時的な温度回復状況から、被圧性の地下 水・不圧性の地下水などその存在状態に関する情 報を得ることも可能である。

\section{(3) 実施方法}

試錐孔内に $50 \mathrm{~cm}$ 間隔に温度計を設置したセ ンサーを挿入し、孔内温度に馿染んた段階で自然 状態の温度を測定する。その後、温水などを注入 して孔内を昇温する。自然状態から十分に温度が 変化した段階で30分程度、孔内温度を測定する (写真 -2 )。

\section{（4）解釈の方法}

測定結果は「温度一深度」曲線（図一7）拈よ び「温度復元率一深度」曲線（図－8）に表現し、 復元率の大小で地下水流動層あるいは地下水浸出 部の検討を行う。

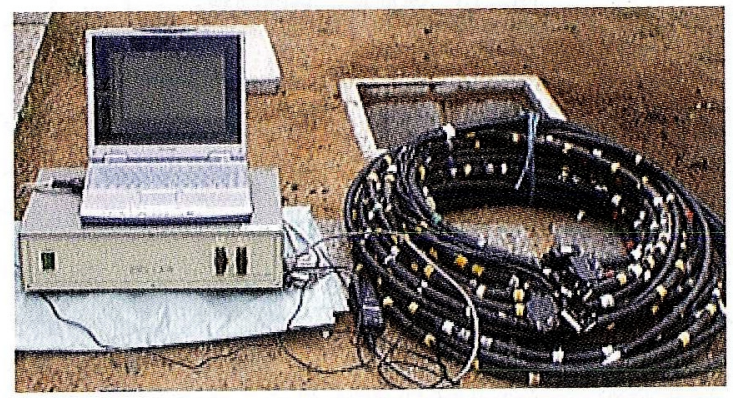

写真一2 多点温度検層一式

\section{3 単孔式加熱型流向流速計}

\section{(1) 概要}

これまで多数の流向流速計が開発されており、 有益な情報を得ているが、大きな問題はセンサー をどの深度に設置するかである。これまでは地質

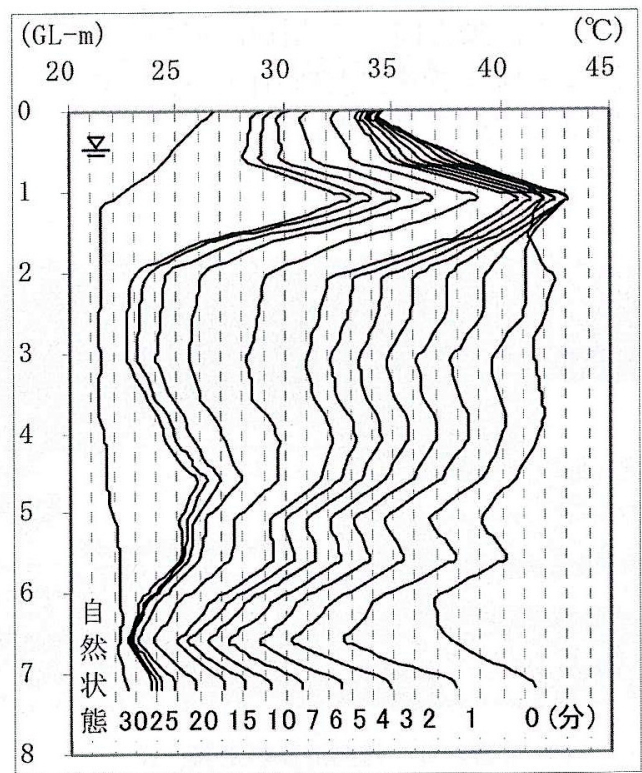

园-7 温度一深度曲線

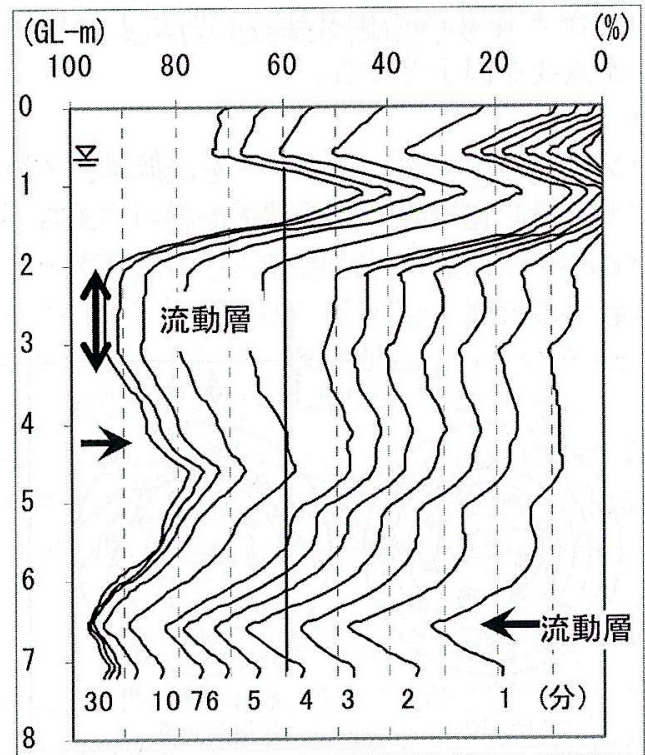

图-8 温度復元率一深度曲線 
柱状図に基づき測定哚度の決定が行われていた が、同一地層内に抢いても地下水の流動状況には 大きな差が認められる。この場合、結果の信頼性 が問題となる。そこで、まず多点温度検層を行い 流動層の存在哚度を調査する。次に、流向流速計 設置深度を決めるという二段階の手法を取ってい る。

地下水の流動方向・流速検出部はヒーターと精 密測温体で構成され、流動方向は磁気式モジュー ルで検出している (写真-3)。

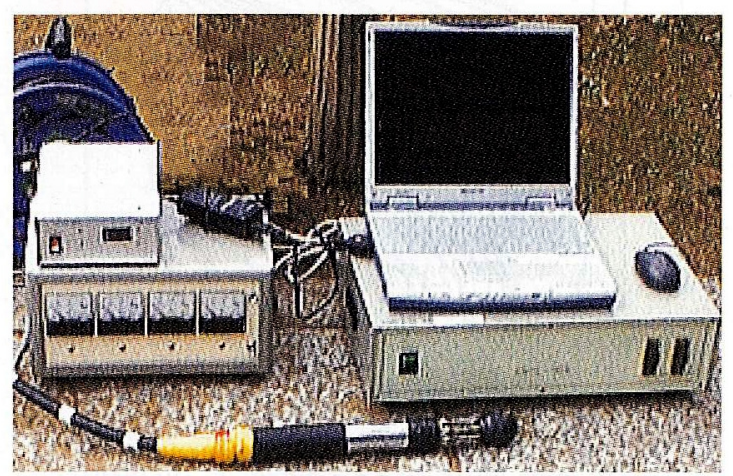

写真 -3 流向流速測定器一式

また、流向流速の計測を行う場合は十分な孔内 洗浄状況と保孔管の開孔率（13\%以上が望まし い）が重要な因子となる。

\section{(2) 原理}

センサーの中央部にヒーターを設置し、その周 囲に8ないし16方向に温度計を配置してある。中 央のヒーターに通電した場合、その熱は次のよう に拡散する（図一9）。

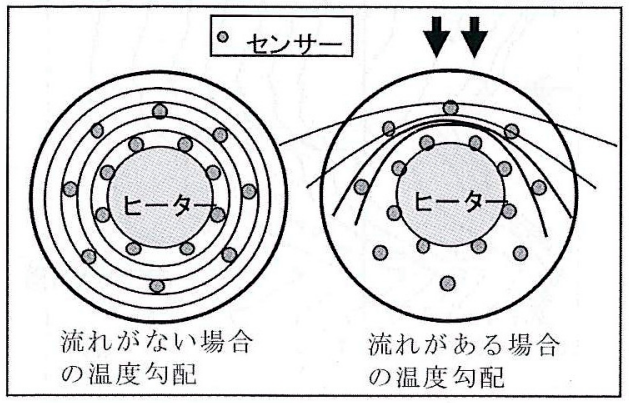

図-9 流向流速測定原理
地下水の流れがない場合はヒーターを中心とし て、同心円状に温度変化が生じる。流れがある場 合は、センサーの上流側では、地下水の流れに よって熱が下流側に移流され温度が低下する。そ のため、温度変化状況はヒーターを中心として偏 芯状になる。この際、一定電圧をヒーターに対し て加電しており、発生する熱量は一定である。し たがって、地下水の流れの状況（流速）に応じた 温度上昇 (温度差) が生じる。これらの現象を利 用することによって、地下水の流動方向や流速に 関する情報を得ることができる。

\section{（3）流速の求め方}

加電前の温度と加電後の温度との差から流速を推 定する。一定電圧をヒーターに与えているため、流 速が大きいほど多くの熱が奪われその温度差は小さ くなる。逆に流速が小さい場合は、奪われる熱量が 小さいため、その温度差は大きくなる。検出された 温度差を、開孔率每に求められた校正曲線に当ては めて流速を算出する（図一10)。なお，地下水流速 の測定範团は 1 〜 $1 \times 10^{-3} \mathrm{~cm} / \mathrm{s}$ である。

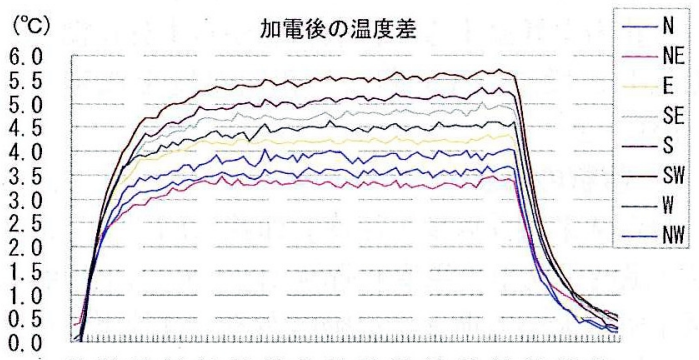

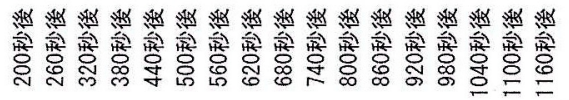

(秒)

\section{図一10 温度差一時間曲線}

\section{（4）流動方向の求め方}

任意時刻に扔ける各センサーの温度分布を描 き、高温部・低温部を検出する。地下水の流入す る側は低温部を示し、下流側は高温を示す傾向が あることから流向を判断する（図－11）。

\section{4 注意点}

\section{（1）孔内洗浄}

地下水調査を始める前に、十分に孔内を洗浄す 


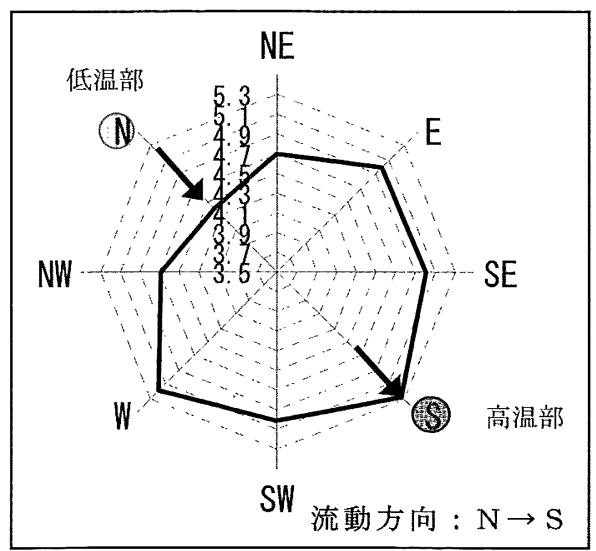

図ー11 任意時刻における等温線図

る必要がある。例えば、掘削洔に形成された泥壁 の存在や目詰まり等によって地下水流が遮断され ている場合は正確な流動層の情報は得られない （竹内 · 渡辺：2004）。

\section{(2) 開孔率}

流向流速測定の際、孔内の地下水流がストレー ナの位置に左右されないよう、開孔率は $13 \%$ 程度 で穴が千鳥に配置してあるのが良い。

\section{3. 自然電位法}

\section{(1) 概要}

自然界には様々な原因によって生じる小さな電 位が存在している。この中に地下水の流動によっ て生じる電位変化がある。この小さな電位変化を 捉えることによって、地下水に関する各種の情報 を得ようとするものである。

\section{（2）測定方法}

電位変化測定法は大きく分けて 2 種類ある。移 動電極法と電極埋設法である。前者は「水ミチ」 の平面的な分布状況を把握するために行われ、後 者は地下水の流動方向と流速に関する情報を得る ために行われる。

\section{1 移動電極法}

一対の電極を一定間隔に保ちながら、移動させ て測定する（図一12）。

電極間隔は調查対象によって異なるが、精度の

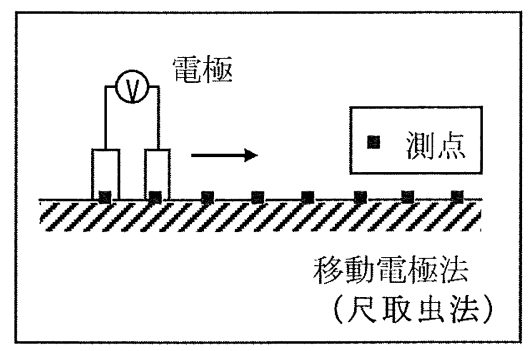

図-12 移動電極法

高い結果を望むのであれば、1～2 $\mathrm{m}$ 程度の電 極間隔で測定する必要がある。測線上に「水ミ チ」が存在する場合は、特有の電位変化が生じる (図-13)。

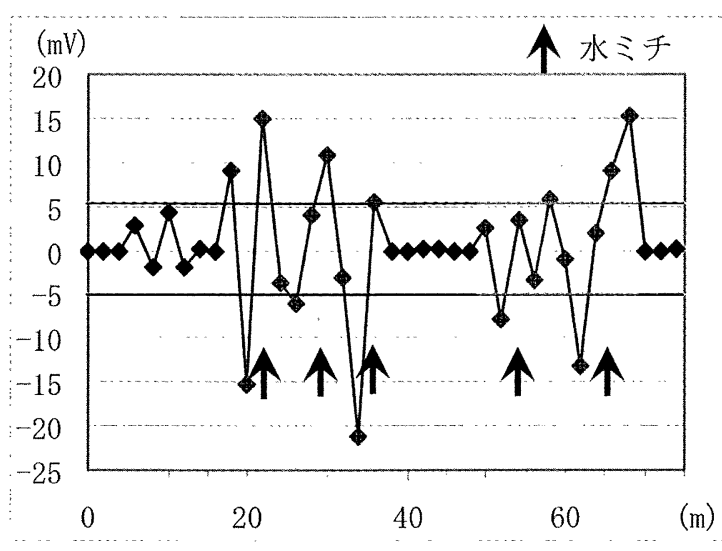

図-13 自然電位接地法測定例

\section{2 埋設法}

主に地下水流向流速調査や堤体漏水確認調査に 用いられている。自然電位を長時間連続記録する 手法で、一方向に一刘の電極を任意の測点あるい は試錐孔を中心として数組埋設する。試錐孔内に は地下水流動層を対象として、電解質溶液（一般 的には飽和塩水溶液）を注入し、溶液の流動力向 と流速を埋設された各電極の電位変化から推測す る(図-14)。これは流動電位法の中の一手法で ある。

また、河川・堤体漏水調査では流動方向に加え それに直交する方向に電極を埋設して測定を行 う。その結果をべクトル合成することで流動方向 の変化を検出する（図一15）。 


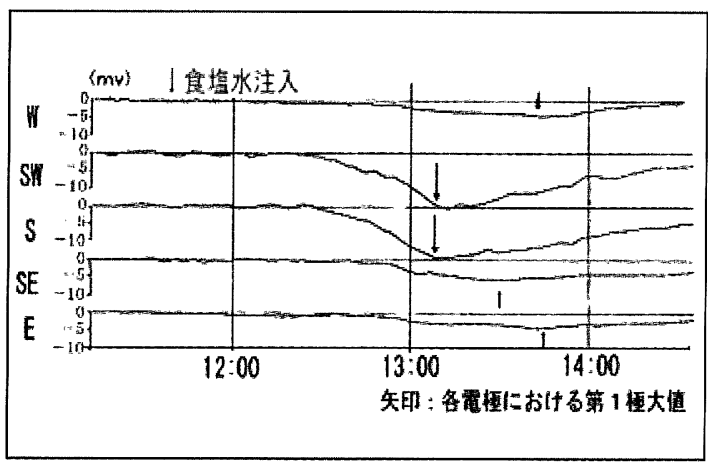

図-14 流動電位法測定例

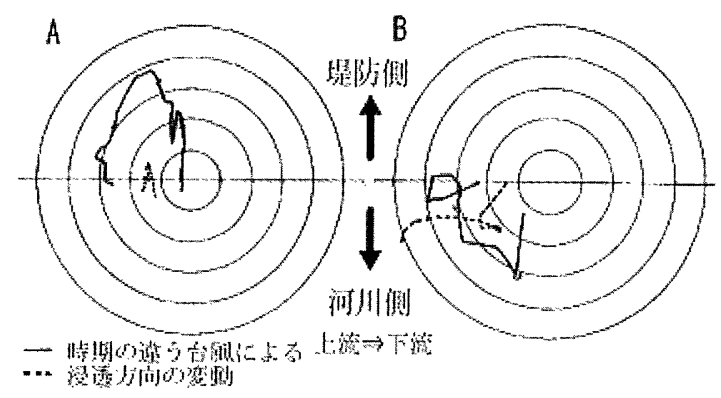

図ー15 ベクトル合成図

\section{3 注意点}

自然界に存在する微弱な電位变化が調查対象と なるため、都市部に扮ける測定では人工的なノイ ズが多く、また金属物が埋設されている箇所では その影響を受ける。

\section{4. まとめ}

上記に述べたように、自然界に存在している 「温度」と「電気」という物理的因子を用いた各種 調査を実施することにより、「あるがままの地下 水の姿」を、定量的かつ三次元的に把握すること ができるのではないかと考える。

\section{5. 今後の展望}

今回述べた諸手法は、当初地すべり地を対象と して適用されてきた。その後、多くの方々のご理
解とご協力により、河川堤防基盤漏水、ため池堤 体漏水、トンネル湧水、河川伏流水、水資源調查 などにその適用範囲が拡大され、最近では社会的 な問題となっている地層污染・地下水污染分野に まで適用範囲が広がりを見せてきている。また、 特殊な適用例としては、樹木の生育と「水ミチ」 の関係、あるいは茸や特殊の草と「水ミチ」の関 係などの調査例も増えてきている。

このような状況から判断すると、今回紹介させ て頂いた調査手法が今後どの様な広がりを見せる か非常に興味あるところである。

今後も計器の改良・計測法の改善に力を尽くす と共に、調査精度とその信頼性の向上に努めて行 くことが大切であると考える。

\section{参考文献}

竹内篤雄（1975）：地すべり活動に対する地下水流脈の 役割について、応用地質、第 16 巻第 3 号、115125.

竹内篤雄 - 内藤光雄 ·松浦健二 (1979) : ある切り取り 斜面に認められた地下水流脈の路頭と $1 \mathrm{~m}$ 深地温と の関係について、第14回土質工学研究発表講演集、 1061-1064.

竹内篤雄（1983）：地すべり 地温測定による地下水調 查法、吉井書店、35-37、134-137.

竹内篤雄（1996）: 温度測定による流動地下水調查法、 古今書院、278-342.

竹内篤雄（1996）: 温度測定による流動地下水調查法、 古今書院、343-366.

竹内篤雄 - 渡辺知恵子 (2004): 孔内洗浄の必要性、地 下水技術、第46巻第 4 号、1-12.

伊藤芳朗・楠見晴重 - 竹内篤雄 (1998) : 斜面調査のた めの物理探査一地すべり・地下水・岩盤評価、吉井書 店、106-134.

竹内篤雄 · 中山健二 ·渡辺知恵子 (2001) : 温度を測っ て地下水を誩断する一あるがままの地下水の姿を探 る、古今書院、125-134.

竹内篤雄・中山健二 ・渡辺知恵子 (2001) : 温度を測っ て地下水を診断する一あるがままの地下水の姿を探 る、古今書院、32-39.

(受付：2005年 2 月 17 日、受理 : 2005年 6 月11日) 